\title{
Sinemada Toplumsal Cinsiyetin İdeolojik İşlevleri: Mor Yıllar Film Analizi ${ }^{1}$
}

\author{
Gönül CENGíz \\ Dr. Öğr. Üyesi, Gaziantep Üniversitesi, \\ Güzel Sanatlar Fakültesi, Radyo, Televizyon ve Sinema Bölümü \\ gonulcengiz88@gmail.com \\ Orcid ID: https://orcid.org/0000-0001-6685-5376
}

\begin{abstract}
Öz
Toplumsal Cinsiyet kavramı son zamanlarda sanatın tüm alanlarında sıklıkla kullanılmaktadır. Bu kavramın geniş kullanım alanlardan biri de sinemadır. Çalışmada 1985 yılında Steven Spielberg'in yönetmenliğini üstlendiği Mor Ylllar filmindeki toplumsal cinsiyet kavramının ideolojik işlevleri açısından incelenmesi amaçlanmıştır. Nitel araştırma yöntemlerinden içerik analizi ve katmanlararasılık (intersectionality) yöntemi bağlamında filmde toplumsal cinsiyetin ideolojik işlevleri, kadın erkek eşitliği, toplumsal cinsiyet rolleri ve cinsellik, sınıf, ırk, din, siyasi farklılıklar ve bunun getirdiği sonuçlar üzerinde durulmuştur. Mor Yıllar filminde, özellikle ideolojik işlevlere özgü ırksal, dinsel, sınıfsal ve cinsel konular, toplumsal cinsiyet rolleri bağlamında incelenmiştir. Film boyunca kadın karakterlerin toplumsal cinsiyet eşitsizliğine karşı göstermiş olduğu tepki, filmin önemli özelliklerindendir.

Çalışmanın sonunda kadınların erkeklere 'ses' çıkardığı ve toplumsal cinsiyet eşitsizliği dengesinin bozulduğu görülmektedir. Filmde aynı zamanda ideolojik işlevler açısından Afro-amerikanların 'beyazlar' tarafından hem ırksal, hem de sınıfsal olarak ezildiği sonucuna varılmıştır.
\end{abstract}

Anahtar Kelimeler: Toplumsal Cinsiyet, İdeolojik İşlevler, Mor Yıllar.

\footnotetext{
${ }^{1}$ Makale Geliş / Kabul Tarihi: 07.12.2020 / 17.05.2021

Künye Bilgisi: Cengiz, G. (2021). Sinemada toplumsal cinsiyetin ideolojik işlevleri: Mor y1llar film analizi. Kahramanmaraş Sütçü İmam Üniversitesi Sosyal Bilimler Dergisi, 18(2), 1102-1115. DOI: 10.33437/ksusbd.836869.
} 


\title{
Ideological Functions of Gender in Cinema: The Color Purple Film Analysis
}

\begin{abstract}
The concept of gender has been widely used in all fields of art. One of the broadest areas of this concept is cinema. In this article, The Color Purple film directed by Steven Spielberg in 1985 is aimed to be examined in terms of ideological functions of the concept of gender. For this purpose, content analysis, which is one of the qualitative research methods, was used and emphasis was placed on empowering women with the ideological functions of gender, gender equality, gender roles and sexuality, class, race, religion, political differences and the results it brought in the context of the intersectionality method. In the film, racial, religious, class and sexual issues specific to ideological functions are intensified in the context of gender roles. One of the most important features of the film is the reaction of female characters to gender inequality throughout the film.
\end{abstract}

As a result of the study, it was found that women give the necessary reactions to men and the balance of gender inequality was disrupted. The film also concludes that in terms of ideological functions, African-Americans are crushed both by racial and class.

Keywords: Gender, Ideological Functions, The Color Purple.

\section{GíRis}

Tarihsel süreçte farklı şekillerde görülen toplumsal cinsiyet rolleri ve dağılımı, çok yönlü boyutları ile kültürden kültüre, dinlere, yaşanılan coğrafyaya, döneme bağlı olarak değişkenlik göstermiştir. Cinsiyet ve toplumsal cinsiyet pek çok kültürde sadece soyun üremesinin yükünü taşıyan bedenlere entegre edilmiş bir kategori olmaktan çıkarak yaşamın tüm yönleriyle sürdürülmesine, yaşamın üretilmesine ilişkin bir dinamikliği anlatan, nötrlüğü dışlayan yaşama dair bir durum olarak bambaşka anlamlara gelebilmektedir (Köse, 2013: 37). Butler (2008: 52) başka deyişle bu durumun bir yandan toplumsal cinsiyet bir yandan da, 'cinsiyetli doğa'nın ya da 'doğal bir cinsiyet'in üretilmesinde ve bunların söylemsellik öncesinde, kültür öncesi bir şeymiş gibi, siyasi olarak tarafsızken kültürün gelip üzerinde etki ettiği bir yüzeymiş gibi tesis edilmesinde kullanılan söylemsel/kültürel araç haline geldiğinin altını çizmektedir.

Toplumsal cinsiyet, sosyo-kültürel bir kökene sahiptir, yani amacı bakımından ideolojiktir. Biyolojik cinsiyet ve cinsellikten tamamen farklı olarak 
görülmelidir. Hayward'a (2012: 523) göre toplumsal cinsiyetin ideolojik işlevinin bir parçası, bu farklılığı gizlemek ve cinsiyet ile toplumsal cinsiyeti aynıymış gibi göstermektir. Toplumsal cinsiyetin ideolojik işlevi biyolojik, fiziksel, toplumsal, psikolojik ve ruhsal yapılara dair heterojen ve belirli bir dizi oluşumu, insan öznelliğine ait bölünemez, sabitlenmiş ve sorunsuz bir nitelik kurmak olmuştur (Kuhn, 1985: 52). Toplumsal cinsiyetin ideolojik işlevi, bizi erkek ya da kadın olarak sabitlemek ve bunu da ilk olarak bizi erkek ya da kadın olarak inşa etmeye hizmet eden ikili karşıtlıklar içinde yapmaktadır. Kuhn'un (1985: 52) da belirttiği gibi bu ikili karşıtlıklar toplumsal, psikolojik, fiziksel ve biyolojik olarak kurulur. Buna göre kadın, ekonomik olarak erkekten değersizdir, kamusal alandan çok ev ile ilişkilidir, daha duygusaldır, erkeğe göre güçsüzdür. $O$ yeniden-üretim alanıdır, erkeğe ait olan üretim alanı değildir.

Hayward'ın (2012: 523) iddia ettiği gibi, 1980'ler boyunca feminist eleştirmenler toplumsal cinsiyet ilişkilerini cinsellik etrafında dönen tartışmaların merkezine yerleştirmiştir. Batı kültüründe erkekler erkekliği toplumsal cinsiyet ilişkileri tarafından belirlenmiş bir durum olarak görmemiştir. Erkeklik üzerine düşünülecek bir konu değildir ve bu yüzden sorunsal olarak kabul edilmemiştir. Kadınlık ise yalıtılmış olarak olmasa bile, toplumsal cinsiyet farklılığ 1 konusunun tartışılmasından başlayarak farklılığın bir parçası olarak görülmeye başlanmıştır.

Aytekin (2018: 68), kadınların kamusal alandan uzak tutulmasının, ataerkil bir ideoloji kapsamında hayatlarını sürdürmelerini bu ideolojinin belirlediği ölçülerle mümkün olduğunu vurgulamaktadır. Bourdieu (2015: 119) ise bu durumu bilgi sahipliği ile açıklamakta, gerek ailelerin gerekse okuldaki yöneticilerin kamusal alanı erkeklere hazırladığı ve kızları da benzer bir teknikle kamusal alandan dışladığıyla ifade etmektedir. Netice itibariyle bilgideki eril düzen, normlarla örtülü bu kalıplarla yeniden üretilmektedir.

Toplumların sosyo-kültürel ve benzeri alanlardaki gelişmeleri, yedinci sanat olarak tanımladığımız sinema aracılı̆̆ıyla gündeme getirilmektedir. Sinemanın ideolojilerin yayılmasında üstlendiği aktif rol ve toplumu yönlendirmedeki başarısı, söz konusu araçların farklı boyutlarda değerlendirilmesini gerekli kılmaktadır.

\section{AMAÇ VE YÖNTEM}

Çalışma toplumsal cinsiyet bağlamında toplumsal cinsiyetin ideolojik işlevlerinin sinemadaki yansımalarını içerik analizi yöntemi ile incelemektedir. Aynı zamanda bu çalışma, cinsiyet, sınıf, etnisite, ırk, din, toplumsal cinsiyet rolleri gibi birçok katmanın birbiri ile iç içe geçmiş olmasından yola çıkarak, bu katmanların birbirinden bağımsız olarak değerlendirilmesinin mümkün olmadığını da savunmaktadır. Genel olarak bakıldığında toplumsal cinsiyet film 
incelemeleri cinsiyet rolleri ve cinsellik üzerine yoğunlaştı̆̆ından, bu çalışmada toplumsal cinsiyet kavramının ideolojik tarafına bakmak amaçlanmıştır.

Katmanlararasılık (intersectionality) bağlamında filmin cinsellik, 1rksal, sınıfsal ve dinsel olarak katmanlarına bakılarak her bir katmanın 'ideolojik işlevler' ile olan bağlantısı toplumsal cinsiyet rolleri açısından incelenecektir.

\section{Cinsellik ve Toplumsal Cinsiyet}

Cinsiyet (gender) ve cinsellik (sex) ayrımı, feminist kuramlar için belirleyici önem taşır. Özellikle Simone de Beauvoir'ın kuramsal yaklaşımı içerisinde cinsiyet, cinsellik tarafından yapılandırılan kültürel bir kimliğin karşıllı̆̆dır (1973: 301). Ona göre 'kadın' olmanın yolu, doğal ve biyolojik bir kendilik olarak kadın cinselliğinin biçimlenmesinin sonucudur. Bu anlamada Taburoğlu (2013: 9) cinselliği, toplumsal cinsiyeti yapılandıran, işaret eden, gösteren bir kavram olarak değerlendirmektedir.

Cinselliğin icrasına özgürleştirici bir işlev bulan Foucault için önemli olan, erkek, kadın ya da lezbiyen olmak değil, tüm bu cinsellik türlerini, yeniden yorumlamaya açabilmek, cinsiyet kimliklerini bozabilmektir. Biyolojik, söylemsel ya da kültürel belirlenmeleri aşmaya dönük olmayan cinsellik konumları, her zaman için güç ilişkileriyle aynı işleyiş mantığına sahiptir. Cinsiyet biyolojik, doğal nedenlerle değil de, güç ilişkilerinin yarattı̆̆ 1 söylemlerle bağdaşık olarak şekillenir. Güç ilişkileri, cinselliğin tüm uygulamalarını cinsiyet kalıpları halinde sabitlemek, belirlenebilir kılmak üzere işler (Taburoğlu, 2013: 14). Toplumsal cinsiyette bu rollerin ayrımı, toplumsal cinsiyet kavramına farklı yaklaşımlar da sunmaktadır.

Toplumsal cinsiyet farklı1ıkları öğrenilen, sosyalleşme sürecinde kazanılan özellikler bakımından insanlar arasında gözlenen farklılıklardır (Dökmen, 2014: 25). Bu bağlamda toplumsal cinsiyet rolleri kadınlara ve erkeklere verilen farklı rolleri karş1lar. Dökmen (2014: 31) aynı zamanda, cinsiyet rolünü, kadına ve erkeğe uygun bulunan kişilik özellikleri ve davranışlar olarak ifade eder ve kültürel beklentilere karşılık geldiğini belirtir. Bir erkek için uygun olduğu düşünülen davranışlar maskülen, kadınlar için uygun olduğu düşünülen davranışlar ise kadınsı (feminen) roller olarak adlandırılmaktadır.

Çok sayıda toplumsal cinsiyet yaklaşımları olsa da makale, konusu gereği ideolojik yaklaşımlarla sınırlandırılmıştır.

\section{Toplumsal Cinsiyete İdeolojik Yaklaşımlar}

Toplumsal cinsiyet ilişkilerini kuşatan iki egemen tartışma vardır; her ikisi de feminist kuram içinde, kültürel incelemelerde, gey incelemelerinde, edebiyat ve 
sinema kuramında kendini göstermiştir. Bu tartışmalar psikanalisttik ve Marxist yaklaşımlarla açıklanmaktadır. Her iki görüş de toplumsal cinsiyet ilişkileri sorununu daha geniş alanlara taşımış ve toplumsal cinsiyetin, ideolojinin bizi inandırdığı gibi basit bir cinsel farklılık konusu değil, aksine toplumsal cinsiyetin zorla dayatılma yolunu saklamak için hiyerarşik güç ilişkisi olduğunun anlaşılmasına yardım etmiştir. Diğer yandan, bu yaklaşımlar toplumsal cinsiyet ilişkileri ile ilgili tarihsel ve toplumsal süreçleri göstermiş, bu ilişkilerin ırk, sinıf ve cinsiyet gibi toplumsal belirlenmelerinin diğer biçimlerinin içine çekebilmesinin yolunu vurgulamıştır. Hayward'a (2012: 524) göre, bu görüşler kültürel uygulamaların toplumsal cinsiyet ideolojisini nasıl yeniden ürettiğini incelemiş ve cinsiyet farklılı̆̆ işlediğinin önemine dikkat çekmiştir.

\section{Psikanalitik Yaklaşım}

Freud'un Psikanalisttik yaklaşımı daha çok cinsiyetin biyolojik süreçlerini ve bu süreçler sonucunda topluma yansıyan etkilerini araştırırken, Jacques Lacan psikanalitik yaklaşımına sosyolojik ve ideolojik boyut katmıştır. Özdeşleme ve içselleştirme gibi bilinçaltındaki süreçleri belirten Freud'un psikanalitik kuramında toplumsal cinsiyete uygun erkeklerdeki erkeksi, kadınlarda ise kadınsı davranışlar sergilemesi küçük yaştan itibaren çocuğun kendi cinsiyetinden ebeveyni ile kurduğu özdeşim süreci ile ilintilidir. Karşı cinsiyete uygun davranışlarda bulunma ise, karşı cinsiyetten olan ebeveyn ile özdeşim kurmakla bağlantılıdır. Çıtak (2008), bu kurama göre, bireyin toplumsal ve psikolojik açıdan uyum sağlayabilmesi için kendi cinsiyetine uygun bir cinsel kimliğe sahip olması gerektiğini vurgulamaktadır.

Lacan'a göre ise, kadının kararlı toplumsal bir cinsiyete kavuşabilmesi için bu maskeyi giyinmesi, olduğundan farklı görünmesi, adeta sahte bir benlik inşa etmesi gereklidir. Kadını erkekten ayrı kılan, taşıdığı cinselliğe dair işaretler değil, içerisine yerleştirttiği söylemin farklılığıdır. Kadın varlığının yaslandığı bu söylem, 'eksiklik' ve 'boşluk'la sınırlanmıştır. Kadın, bu söylemsel yapılaşmamışlık içerisinde, cinsine ait bir göndergeye yaslanamadığında bu 'sahteliği' yaratabilmesi kaçınılmaz olmaktadır. Erkek-olmayanlar, erkek dünyasında varolan 'arzu ekonomisi' içerisinde gezinerek cinsiyetlerini yaratmak zorunda kalırlar. Maske, özellikle kadının 'kendi sahip olduğuna' yabancılaşması pahasına takması zorunlu olduğu bir örtüdür (Tura, 2016: 41). Bu yüzden Lacan'ın kadınlığın ortaya çıkışıyla, ilgili ruhbilimsel anlatısında, kadın olmanın, kaybedilene özlemle, 'melankoli'yle birlikte deneyimlendiğini belirten Taburoğlu (2013: 12) kadının, her zaman tanımlayamadığı kayıp bir nesnenin, eksiğin özlemiyle, var olmak zorunda kaldığına dikkat çeker. 
Psikanalitik yaklaşım, ataerkil dilin cinsiyetlendirilmiş öznelliği sürdürmeye nasıl hizmet ettiğini ve hiyerarşik olarak nasıl belirlenimci olduğunu gösterir. Lacan'cı yaklaşım, cinsiyet ilişiklerinin köklerinin dilbilimsel alanda temellenen iktidar ilişkilerinde olduğunu görmeyi olanaklı kılmakta ve toplumsal cinsiyet ilişkilerinin ideolojik işleyişlerini açığa vurmaktadır (Tura, 2016: 25).

\section{Marksist Yaklaşım}

Psikanalitik yaklaşım toplumsal cinsiyet ideolojisine meydan okumanın yolunu gösterse de bunun dil düzeyinde olacağını varsaymaktadır. Hayward (2012: 524), toplumsal cinsiyetin sadece dil aracilığıyla değil, toplumsal atıflar ve kültürel pratikler yoluyla yapılandırıldığını söylemektedir. Karaca’ya (2018) göre Marxist materyalistler, toplumsal cinsiyet ideolojisini ikili hat üzerinden inşa etmeye çalışarak onu toplumsal ve kültürel bir yapı olarak görmektedirler. Böylece toplumsal cinsiyet ideolojisi çeşitli kültürel pratikler içinde temsil edilmektedir.

Marx'a göre, insanların birbirleriyle ilişkileri, ekonomik yaşamdaki rollerinin bir sonucudur. $\mathrm{Bu}$ nedenle, toplumsal cinsiyet eşitsizliğinde, ekonomik ilişkileri göz önünde bulundurmakta fayda vardır. Marksist bakış açısıyla toplumsal cinsiyet oluşumunun temelinde üretim araçlarının kullanımı ve özel mülkiyet anlayışının erkeğe sahip olma hakkını vermesi, biyolojik cinsiyete yönelik yüklemelere ve ataerkillik anlayışına dayalı olması toplumsal cinsiyetin temel noktasını oluşturur. Marksizmin kadınların ezilmişliğgi sorununa bakışı, aslında Marksist yöntemin topluma ve toplumsal değişime yaklaşımıyla ilişkilidir. "Özel Mülkiyet ve Komünizm” de, kadınların konumunun toplumun gelişiminin bir ölçüsü olduğunu savunan Marx kadınların kapitalizm şartları altında ezildiğini de vurgular (Belkhir, 1993: 143). Marksist teori, aynı zamanda kadının ekonomik anlamda erkeğe bağımlı hale gelmesinin onu diğer sosyal alanlarda da erkeğe bağlı duruma getirdiğini vurgulamaktadır. Kadının bağımlı yaşam şekli onu 'ikinci cins' olarak belirleyen önemli etkendir. Özellikle ev ve aileye bağlı olarak yaşamakta olan kadın özel hayata kapatılarak, kamusal alandan bilinçli bir şekilde uzak tutulmuştur. Marksist feministler için kadının kamusal alana çıkıı̧ını engelleyen en temel faktör kamusal ve özel alan ayrımına göre tasarlanmış çağdaş kentlerdir. Ekonomik sosyal aktiviteler olan eğitim, ticaret, üretim gibi etkinliklerin hepsi aileden koparılmış ve aileden uzak yerlerde kurumsallaşmışladır (Pehlivan, 2017: 514).

Connell’e (1998) göre, kadınların sömürülmesi, kapitalizmin kar sağlama dürtüsü, işgücünün cinsiyete dayalı bölünmesine ve ev kadınlarının ezilmesine yol açmaktadır. 
Toplumsal cinsiyet kavramı doğrudan Marksizme hitap etmese de, Marksist yaklaşımda 'toplumsallığın' tarihsel süreçler ve sınıfsal ilişkiler içinde anlam bulduğuna vurgu yapmaktadır Karaca, 2018).

\section{Sinemada Toplumsal Cinsiyetin İdeolojik İşlevleri}

\section{Siyasal İşlev}

Farklı ideolojik programların, söylemsel kurulumların ve yapısal önceliklerin feminist siyasetle, feminist taleplerle ve feminist sözle ilişkilenme biçimleri olası içsel çelişkilerinin, hegemonya taleplerinde dolaşıma sokulan sözlerin politika tercihleriyle kurduğu bağın açığa çıkartılması açısından önemli işleve sahiptir (Çoşar, 2013: 22).

Çoşar (2012: 28) aynı zamanda, kadın hareketi içerisinde yer alan örgütlerin büyük bir çoğunluğun toplumsal cinsiyet eşitliği için verdikleri mücadelelerde, üzerine odaklandıkları sorun alanlarında faal olabilmek için mevcut sorunun siyaseten ve toplumsal olarak önemini serbest piyasa terimleri üzerinden kanıtlama koşuluyla yüz yüze kalmanın yanı sıra- ve bu duruma paralel bir şekilde- finans kaynaklarına erişim sürecinde rekabet ortamına da girmek durumunda kaldıklarını vurgulamaktadır.

Connell (2005: 5), bütün muhafazakâr politikanın kendisini 'geleneksel aile', 'doğru dişilik' ve 'gerçek erkekliği' yeniden kurmaya adadığını belirtmektedir. Tüm bunlar toplumsal cinsiyet belirsizliklerini ortadan kaldırmaya yönelik hareketler olarak değerlendirilmektedir.

\section{Dini İşlev}

Kroska (2000), cinsiyet ideolojisinin bir inanç sistemi mi yoksa bir kimlik olarak mı değerlendirilmesi gerektiğini sorgulamaktadır. Denton (2004), din ve inançların cinsiyetle ilgili yönleri arasındaki ilişkinin karmaşık olsa da (Denton, 2004), artan dini uygulama düzeylerinin geleneksel bakış açılarını güçlendirmesi ve cinsiyet eşitliği için desteği azaltmasını beklediğini vurgulamaktadır. Dahası, dini doktrinler içinde yer alan belirli ilkeler genellikle cinsiyet ilişkilerine, kadınların ve erkeklerin çocuk sahibi olma konusundaki göreceli sorumluluklarına odaklanmaktadır. Bu nedenle dinlerin cinsiyet ilişkileri ile ilgili öğretilerinde farklılık göstermesi ve dolayısıyla inançlı erkekler ve kadınlar arasında farklı ideolojilere yol açması beklenmektedir. Davis ve Greenstein (2009: 94) iddia ettiği gibi dinsel bağl1lık ve kişisel dini inançlar, toplumsal cinsiyet ideolojisini, heteroseksüel evliliklerde güç paylaşımının uygunluğuna ilişkin anlatılar oluşturarak etkilemektedir, ancak bu süreç sosyal sınıf tarafından yönetilmektedir. 


\section{Irksal ve Etnik Isslev}

Toplumsal cinsiyet ideolojilerindeki 1rksal ve etnik farkl1lıklar, 1 rk ve etnik kökene göre ırk ile cinsiyet ve toplumsal sınıfın kesişme noktalarının bir işlevi gibi görünmektedir.

\section{Sınıfsal İşlev}

Toplumsal cinsiyet ideolojiyi popüler kültürde ve sinemada; imgeler, şekiller, görseller, genel kodlar ve sinematik aygıt biçiminde sunmaktadır.

Fakat toplumsal cinsiyetin ideolojik işlevindeki sınıfsal boyut Marksist ideoloji teorisi bağlamında ele alındığında ideoloji kavramı sınıf egemenliği olarak vurgulanmaktadır.

Hangi cinsiyet, 1rk ya da cinsellik olursa olsun, zengin ve güçlü sınıfta olanlar, ideolojinin nasıl oluştuğunu ve kapitalizmin nasıl kurulduğunu kontrol edenlerdir.

Toplumsal cinsiyetin ideolojik işlevi denildiğinde akla gelen ilk kavramlardan biri de toplumsal sinıftır. Bourdieu'ya (1984: 250) göre, sınıflar kendilerini yalnızca ekonomik durumlarıyla değil aynı zamanda davranış, tercihler, görüşler ve zevkle açıkça sergilenen kültürel ve eğitsel sermayeleriyle de ayırmaktadır.

Kellner (1991: 2), ideolojiyi sınıfsal çıkarlara indirgemek, toplumda devam eden tek önemli tahakkümün sınıf veya ekonomik tahakküm olduğunu ortaya çıkarırken, birçok teorisyenin cinsiyet ve ırk baskısının da temel öneme sahip olduğunu ve aslında bazılarının temelde iç içe olduğunu savunduğunu ortaya koymaktadır.

\section{Cinsellik İşlevi}

Filmlerde yüksek oranda temsil edilen bir başka ideoloji de cinselliktir. Cinsellik kavramı çok farklı anlamlara gelmektedir. Bu anlamlar içerisinde cinsel yönelim, heteroseksüellik, eşcinsellik, biseksüellik ve hatta aseksualalite (cinsel arzu ya da tercihlerin olmaması) kavramları en çok kullanılanlardır.

Sinemada cinsellik olgusu aynı zamanda bir erkek ya da kadın olarak doldurmamız gereken ve anlam yüklediğimiz rollerin bir ideolojisini temsil etmektedir (Shirts, 2012) Birçok filmde erkekler güçlü, cahil, spor odakl1, duygusal olarak daha az etkileyici, işçi, avcı, bağımsız olarak tanımlanırken, kadınlar ise evde oturmayı seven zayıf, aile bireylerini büyüten, duygusal, muhtaç ve birine bağımlı varlıklar olarak karakterize edilmektedirler. Bu anlamda filmlerin çoğu, kimliğimizde başarılı olmamızı, güvenilmemizi, kabul 
edilmemizi, sevgiyi bulmamızı ve toplumda iyi iş yapmamızı gerektiren harika görünümlü bir kadroya sahiptir.

\section{Toplumsal Cinsiyetin İdeolojik İşlevleri Bağlamında Mor Yıllar Film Analizi}

Alice Walker tarafından kaleme alınan "Mor Yıllar" romanını beyaz ekranlara taşıyan yönetmen Steven Spielberg, bir kadının erkek egemen toplumlarda sesini, özgürlüğünü ve kendine değer bulma yolunda geçen uzun yolculuğunu izleyicilere sinematik yolla aktarmıştır. Sanatın diğer dalları olan radyo tiyatrolarına ve müzikallere de başarılı bir şekilde uyarlanan "Mor Yıllar" romanının film uyarlaması ırk, sınıf ve toplumsal cinsiyet ayrımcılığına maruz kalmış Afro-amerikan bir kadının hayat hikayesini anlatmaktadır. Film sürekli şiddete maruz kalan kadınların bu duruma ses çıkaramadığına da vurgu yapmaktadır.

Utangaç, umutlu ve Tanrıdan korkan siyahi Amerikalı, Celie, erken ergenlik yıllarından itibaren sert, baskın, dul bir siyahi olan Bay Albert Johnson'la zorla evlendirilmiştir. Babası ve kocası tarafından istismara uğradığını ve dövüldüğünü bilmesine rağmen, onlara karşı çıkmamıştır. Diğer taraftan, trajik rolünü itaatkar bir kadın ve eş olarak kabul eden Bayan Celie, bir kadın ve bir birey olarak kendi kimliğini özlemekte ve başka bir kadın aracılığıyla da bu özlemine kavuşmaktadır. Filmi toplumsal cinsiyetin ideolojik işlevleri bağlamında incelersek, rrk, cinsiyet, sinıf ve cinsellik boyutları film boyunca ön plandadır.

\section{Irksal işlev}

Filmdeki ırk ve sınıf gerilimleri, Amerikan İç Savaşı'ndan sonra, özellikle de 1900'lerin başlarından 1937'lere kadar köleliğin kaldırılmasına karşı çıkan Güney eyaletlerindeki Afro-amerikanların yaşadıkları zorlukları anlatmaktadır. Siyahi köleler Abraham Lincoln'un Özgürleşme Bildirgesi ve On dördüncü ve On Beşinci Değişikliklerin kabul edilmesiyle Amerikan vatandaşlığından ve oy haklarından yararlanarak özgür olsalar da, hâlâ ayrımcılığa uğramaya devam etmiş, azınlık olarak kabul edilmiş ve beyaz Amerikalıların ekonomik ve politik olarak hâkim olduğu Amerikan toplumundan tecrit edilmişlerdir. Bu tür ayrımcılıklar ve haksız muameleler beyaz toplum tarafından yasallaştı̆̆ için Afro-amerikanlar duruma boyun eğmek zorunda kalmıştır.

Filmde ırksal ayrımcılık özellikle siyah karakterlerin (Celie, Corrine Mcgrady ve Sofia) beyaz Amerikalılarla ilişkilerinde belirgin olarak görülmektedir. Örneğin, Corrine Mcgrady bez alırken, beyaz dükkan sahibi tarafından gergin ve kaba bir muamele görmektedir. Kumaş satın alacak başka müş̧eri olmamasına rağmen, dükkan sahibi Corrine'dan alıș veriș yapıp yapmadığını kabaca sorar. Bir başka örnek ise, Sofya'nın Belediye Başkanı Bayan Millie ve şehir merkezindeki 
diğer beyazlar tarafından nasıl muamele gördügüdür. Belediye başkanının karısı Bayan Millie, Sofya'nın çocuklarına ne kadar temiz olduklarını söyler ve onlara hizmetçi olmak isteyip istemediklerini sorar. Teklifinin kabaca reddedilmesi belediye başkanı eşini ve diğer beyazları sinirlendirir ve Sofya cezalandırılır. Filmde Sofya'nın üzücü kaderi, beyazlar ve siyahlar arasındaki güç ilişkilerinin boyutunu da vurgulamaktadır. Egemen toplum olan beyazlar politik ve ekonomik olarak her şeyi kontrol etmektedir.

Afro-amerikanlar genel olarak beyazlar tarafindan yönetilseler de, dini görevlerini yerine getirmek için gittikleri Protestan kilisesinin yönetimi kendilerinden olan bir din görevlisi tarafindan yürütülmektedir.

\section{Sınıfsal İşlev}

Filmde beyazlar, siyah Amerikalılar'dan daha zengin olsa da, Shug Avery ve kocas1 Grady gibi durumu iyi siyahiler de gösterilmektedir. Beyazlar şehir merkezinde yaşayarak şehri kontrol altında tutmakta, Afro-amerikanlar ise tarlalarda çiftçilik yaparak şehir dışında yaşamaktadırlar. Kasaba merkezinde yaşayan Afro-amerikanlar ise beyazların hizmetçisi olarak çalışmaktadır. Filmde Afro-amerikanlar, beyaz topluluklardan uzak kendi topluluklarında yaşamlarını sürdürmektedir. Beyazlar kiliselerde bile siyahların arasına karışmamaktadır. Siyahilerin bölgesine giden tek beyaz insan postacidır.

\section{Cinsiyet İşlevi}

Filmde, Celie, aktif, otoriter erkekler tarafindan yönetilen basmakalıp itaatkar, pasif ve uysal kadını temsil etmektedir. Ataerkil bir toplumda yaşayan Celie, önce babasına ve daha sonra kocasına itaatkar olmaya zorlanır. Babası ve kocası tarafından istismara uğradığını ve dövüldüğünü bilmesine rağmen, onlarla savaşmaz. Ataerkilliğin çok baskın işlendiği filmde kadınlar çoğu zaman cinsel nesne olarak da görülmekte ve tek işlerinin ev ve çocuklar olması gerektiğinin altı çizilmektedir. Erkekler her şeyi kontrol eder ve karılarının rolünü belirler.

Filmde önemli vurgulardan biri de cinsiyet ayrımına yapılmaktadır. Birçok toplumda geleneksel yapı olarak kadınlar daha zayıf, erkekler ise daha güçlü ve egemenken bu dengeler zaman zaman bozulmaktadır. Filmde kadınların güçlendiği, erkeklere karşı durabilecek ve bağımsız olarak yaşayabileceklerini temsil eden Netie, Sofia ve Shug Avery gibi kahramanlar da vardır.

Nettie cesur, zeki ve eğitimlidir. Baskıya ve şiddete dayanamadığından babasını terk etmiş; Bay Albert'in tecavüz girişimini engellemiştir. Bay Albert'in evinden kovulduktan sonra ise sokaklarda yaşamak yerine, Mcgrady tarafından evlat edinilmiş ve Afrikalı çocukları eğiten anne-babasına yardım etmiştir. Bilginin yaşamdaki önemini anlayan Netie, Celie'ye okunmasını söyler ve Afrika 
kültürünün ne kadar zengin olduğunu öğretir, böylece Celie bilgi kazanarak ırkıyla gurur duyar. Filmde Sofya karakteri açık sözlü, iddialı ve dürüst bir kadındır. Nettie ve Sofya arasındaki en büyük benzerlik şiddete maruz kaldıklarında özgür kalmayı tercih etmeleridir. Shug Avery ise kaygısız, maceracı ve bağımsız bir kadındır. O, Bay Albert'ten korkmamaktadır. Amacını sürdürmek ve insanlar tarafından sayg1 görmek için güzelliğini ve yeteneğini kullanmaktadir.

Sofya'nın gücü ve öfkesi, Shug'un saldırgan davranışı ve cinsel iddiası kadın karakterlerin cinsiyeti ile gösterdiği özellikler arasında tezadı göstermektedir. Film bu inanc1, karakterlerin görünümü ve hareketleriyle yeniden doğrulamaktadır. Sofya, Harpo'ya tabi olmayan sağlam bir kadın ve Harpo erkekliğinden emin olmayan zayıf bir adamdır; Shug gösterişli kıyafetler giyer ve Albert üzerinde egemendir. Bu karakterlerin hiçbiri geleneksel erkek ve kadın cinsiyet rollerini karşılamamaktadır ve onlar gibi kadınlar ataerkil toplumda kabul edilmemektedir.

\section{Cinsellik İşlevi}

Filmde seks, bir şiddet şekli olarak özgürlük ve mutluluk kazanmanın bir aracı olarak gösterilmektedir. Celie'nin babası Celie'ye çirkin olduğunu belirterek cinsel nesne olarak kullanmıştır. Bu Celie'nin kendine saygısını ve değerini kaybetmesini sağlamış, onu güçsüz ve her şeye boyun eğen biri haline getirmiştir. Daha da kötüsü, babası Celie'nin bebeklerini satar ve annesine söylememesi için onu tehdit eder. Bay Albert ayrica Celie'ye cinsel bir nesne olarak davranmakta, onu dövmekte ve onu sadece kendi memnuniyeti için kullanmaktadır. Bu nedenle Celie, cinselliği özel ve bir çeşit takdir şekli olarak değil, tamamen erkek tarafından kontrol edilen bir faaliyet olarak tanır. Albert'in sevgilisi olan Shug, Celie'nin sevgi eksikliğini fark eder ve ona gerçek şefkatli sevişmeyi sunar. Celie, ilk defa, bir kadının elinde olmasına rağmen, gerçek cinsel hazzı yaşar.

Celie ve Shug arasındaki lezbiyen ilişkisi, bu temayı belirsiz cinsellik ile sınırlandırmaktadır. Cinsiyet özelliklerinin bulanıklaşması ve cinsel belirsizlik nedeniyle, film toplumun erkek ve kadın davranışı olarak sınıflandırdığ geleneksel yöntemlere meydan okumaktadır.

\section{Dinsel İşlev}

Bir ırk ve sinıf olarak, Afro-amerikalılar filmde dindar olarak tasvir edilmektedir. Celie, kurtuluşu için daima Tanrı ile iletişim kurar ve yaşamındaki zorluklarla yüzleşirken akı1 sağlığını korur.

Celie sık sık 'Sevgili Tanrım' ibaresini kullanmakta ve Harpo'nun karıs1 Sofyayı dövmesini öneren Celie Sofya'yla karşılaştığında: "Bu hayat yakında 
bitecek. Cennet her zaman sürecek" diyerek dine olan bağl1lı̆ğnı belirtir. Celie'nin karşılaştığı tüm zorlukların üstesinden gelmeye çalışması daha yüksek bir varlığa güçlü bir inancı sürdürdüğünün de göstergesidir.

\section{Özgürlüğün, Eşitliğin ve Kadınlığın Temsili: Mor}

Shug, Tanrı'nın mor çiçeklerle dolu bir alanda yürüyebilen ve onları fark etmeyen insanlara kızgın olduğuna inandığını söylemektedir. Bu bize morun özgürlüğü temsil ettiği ve Tanrı'nın belirli bir ırk veya belirli bir cinsiyet olmadan, hepimizi olduğu gibi sevdiği hissini vermektedir. Celie ve Nettie filmin başlangıcında mor bir alandayken birbirlerini sever, kendilerini özgür hissederler. Mor renk kadın eşitliğinin ve mücadelesinin rengi olduğundan Spielberg filmde kadınların yaşadıkları süreçleri Mor Yıllar olarak tanımlamaktadır.

\section{SONUÇ}

Film, cinsiyet ve cinselliğin hiç de basit bir olgu olmadığını vurgulamaktadır. Ataerkil toplumlarda kadınların değersizleştiğinin altını çizen yönetmen, filmde Celie'i erkeklere bağımlı, tek görevi ev ve çocuklarla ilgilenmek olan cahil ve duygusal bir varlık, aynı zamanda da cinsel bir nesne olarak göstermiştir.

Film, bir taraftan kadının erkek egemen toplumunda ezildiğini gösterirken, diğer taraftan erkeklere karşı durabilen ve bağımsız olarak yaşayan Netie, Sofia ve Shug Avery gibi kadın karakterleri de izleyiciye göstererek kadına farklı bakış açısı sunmayı başarmıştır. Filmin sonunda, erkek egemenliğinin ve kadınların baskı altında kalmasının kalıcı olmadığı ve bu durumun değişebileceği gösterilmiştir.

Toplumsal cinsiyeti ideolojik işlevler açısından ele aldığımız bu çalışmada Afro-amerikanların hem irksal, hem dinsel, hem de sinifsal olarak 'beyazlar' tarafından ezildiği görülmektedir. Filmde bir taraftan toplum olarak da beyazlardan uzakta yaşayan, onların hizmetçisi olarak çalışan Afroamerikanların ırksal mücadelesini izlerken, diğer bir yandan kadınların erkek egemenliğine karşı durabildiği ve sonunda toplumsal cinsiyet eşitsizliğine meydan okumayı başardıkları, bununla da filmin başında görülen cinsiyet rollerindeki dengeyi değiştirebildikleri izlenmektedir.

\section{KAYNAKÇA}

Aytekin, M. (2018). Sinemada söylem ve ideoloji: Samira Makhmalbaf filmleri üzerine bir inceleme. Akdeniz Araştırmaları ve Toplumsal Cinsiyet Dergisi, 1, 59-76. 
Belkhir, J. A. (2001). Marxism without apologies: Integrating race, gender, class; a working class approach. Race, Gender \& Class, 8(2), 142-171.

Bourdieu, P. (1984). The field of cultural production: Essays on art and literature. USA: Columbia University Press.

Beauvorr, S. (1973). The second sex. Vintage Books.

Butler, J. (2008). Cinsiyet belast: Feminizm ve kimliğin altüst edilmesi. Metis Yayınc1l1k.

Connell, R.W. (1998). Toplumsal cinsiyet ve iktidar toplum, kişi ve cinsel politika. Ayrıntı Yayınları.

Connell, R, W. (2005). Hegemonic masculinity: Rethinking the concept. Gender\&Society, 19(6), 829-859.

Çıtak, A. (2008). Kadınların çallşmasına yönelik tutum: Cinsiyet, cinsiyet rölü ve sosyoekonomik düzeye göre bir karşılaştırma. [Yüksek Lisans Tezi]. Ankara Üniversitesi.

Çoşar, S. ve Kerestecioğlu, İ. (2013). Feminizmin neoliberalizmle imtahanı. Doğu Batı Düşünce Dergisi, 64, 21-36.

Denton M,L. (2004). Gender and marital decision making: negotiating religious ideology and practice. Soc. Forces 82, 1151-1180.

Dökmen, Y. Z. (2014). Toplumsal cinsiyet, Remzi Kitapevi.

Hayward, S. (2012). Sinemanın temel kavramları, (Çev. Uğur Kutay, Metin Çavuş). Es Yayınları.

Karaca, S. (2018). Marksist kaynaklardan 'cinsiyete' bakmak: Bir okuma denemesi. https://teoriveeylem.net/2018/05/marksist-kaynaklardancinsiyete-bakmak-bir-okuma-denemesi/ Erişim: 12.09.2019.

Kellner, D. (1991). Film, politics, and ideology: Reflections on Hollywood film in the age of reagan. University of Texas at Austin (University of Texas Press).

Kroska A. (2000). Conceptualizing and measuring gender ideology as an identity. Gender\&Society. 14(3), 368-394.

Köse, E. (2013). Cinsiyet/Toplumsal cinsiyet ikiciliği üzerine eleştirel yaklaşımlar ya da doğa “doğal mıdır?”. Doğu Batı Düşünce Dergisi, 64. 
Pehlivan, P. (2017). Toplumsal cinsiyet bağlamında kuramsal yaklaşımlar: bir literatür taraması. İstanbul Ticaret Üniversitesi Sosyal Bilimler Dergisi, 16(31), 497-521.

Shannon N. D. and Greenstein, T, N. (2009). Gender ideology: Components, predictors, and consequences. Annual Review of Sociology, 35, 87-10.

Shirts, B. (2012). Race, Class, Gender, and Sexuality on Film, http://brianshirtsfilmclass.blogspot.com/ Erişim: 10.09.2019.

Taburoğlu, Ö. (2013). Queer kuramı: Yapılaşmamış kimlikler, keyfi cinsiyetler. Doğu Batı Düşünce Dergisi, 64.

Tura, S. M. (2016). Freud'dan Lacan'a psikanaliz. 6. Bask1, Kanat Kitap. 